\title{
The Politics of Issue-Based Political Campaign in Nigeria
}

\author{
Fred A. Amadi $(\mathrm{PhD})$ \\ Senior Lecturer on the Departmental Board of Mass Communication \\ at the Rivers State University of Science and Technology, Port Harcourt, Nigeria
}

\begin{abstract}
This paper explores how Nigerian politicians respond to the flaws that dog political campaigns in a fledgling democracy. The paper identifies three flaws: (1) indiscriminate extension of the voting right to everybody of eighteen years and above (2) absence of balance and fairness in media practice (3) the obsession by the media to practice snippet journalism. The paper investigated how these flaws are implicated in politicians' proclivity to run campaigns that are not issue-based. To accomplish the investigation, I theoretically sampled newspaper texts of 2011 general elections in Nigeria. The texts were presented in a titled table. Critical Discourse Analysis was used to analyze the texts. Analysis provided a ground to hypothesize that indiscriminate extension of voting right to every person of 18 years and above in a fledgling democracy will lead to a situation where majority of the electorates will be naïve to a degree that will make politicians to often see no reason to run intelligent, issue-based campaign.
\end{abstract}

Keywords: Politicians, electorates, Issue-based campaigns, voting rights

\section{Introduction}

Political communication pundits have stopped worrying about the best system of government. They have stopped worrying because democracy has been affirmed as the best system of government (Hahn, 1998; Mayhew, 1997; Keane, 1995; Melody, 1990; Webster, 2011). What has remained a matter of concern is what nations need to do in order to reap the benefits of democratic governance.

By many standards, the United States and many countries in Europe practice the best standards of democracy. The Western world had paid a price before their democracy attained its present enviable status. Before they attained the status, Europe and the United States had refined both their political communication and the quality of their electorates.

\section{Political Communication in the Feudal era}

During the Feudal era, Europe practiced the transmission model of communication (Chandler, 2010; Anderson \& Ross, 2002; Reddy, 1979; Hardt, 2004). The Feudal Lords, the Emperors and the Queens used their influence to promote the transmission model of communication. In the Feudal era, the Scrittorid'arvisicarried out communication duties for the Kings, Queens and the Emperors (Kunczik, 1995, p.15).Part of the responsibilities of the scrittorid'arvisi was to publish imperial decrees. In addition to that, the scrittorid'avissi took advantage of the decree-medium to also publish news. In those days, news gathering was easy. News was a little more than the experiences that the scritoridavsi encountered as they ran diplomatic errands for their overlords (Kunczik, 1995).

The transmission model of communication as practiced by the scrittorid'arvisi made information-dissemination to be one-sided - from the sender to the receiver. The one-sided model waned as soon as the bourgeoisie felt, in different European states, that the transmission model of communication was not giving them a say in political matters. The bourgeoisie's dissatisfaction with the transmission model of communication compelled them to seek a model that guaranteed active participation in communication. Active participation of the bourgeoisie in debating social issues ushered in the transactional model of communication. The bourgeoisie practiced the transactional and debating model in clubs known as Tea Houses in England, Salons in France and Tischgesellschaften in Germany (Habermas, 2001; Gripsrud, 2002). When the debating activism of the clubs grew in popularity, the bourgeoisies sought and gained wider audience for their activism through the establishment of newspapers. By the early part of the seventeenth century, a handwritten newspaper - Nurnberger Nachrichen(Nuremberg News) and OrdinariZeitung by Fugger had appeared in Germany. The same trend occurred in Holland in 1618, France in 1620, Britain in 1620 and Italy in 1636 (Kunczik, 1995, p. 15). The editorial outlook of those papers owned and published by "men of letters" was to hold the "ruling authorities" of that time as "adversaries" (Habermas, 2001, p. 26). 
The ownership of the media by learned and well-to-do men in ancient Europe guaranteed that media practitioners then were personalities that never sacrificed editorial sanctity on the altar of pecuniary benefits. The choice of "ornate" and "elegant language" in the communication practice of the bourgeois era (Habermas, 2001, p. 11f) also guaranteed that the bourgeoisie of ancient Europe practiced a communication model that bore the hallmark of rational discourse (Gouldner 1979, P. 39 \& 49). When rational discourse features in communication practice, practitioners often demand that "speakers' statements be challenged in a way that makes communication become a systematic argument that makes special appeal to speakers to demonstrate the validity of their claim" (Littlejohn, 1996, p.233).Rational discourse dovetails into what is now promoted as "public" or "civic" or "communitarian journalism" (Anderson \& Ross, 2002, p.291; Friend, Challenger \& McAdams, 2000, p. 228; Rosen, 1999). Public journalism endorses a style of reporting that seeks out trends and patterns rather than reacting to events. Civic journalism sees its mission not as a mere source of information, but a facilitator of public debate and, sometimes, an active leader in that debate. It believes that news coverage should not merely report, but should engage and involve the people. Public journalism sees journalism practice as a public trust. For this, it demands that all practitioners connected with it be seen as trustees for the public. It insists that a lesser service is a "betrayal" of that trust (Rosen, 1999, p.1). The core tenet of public journalism encourages societies that aspire to get the best out of the democratic system to refine their political communication in ways that accommodate the imperatives of public journalism.

\section{Refining the Electorates for Democratic Participation}

The democratic system of government is a legacy bequeathed to humanity by Europe. Right from when the democratic experiment was in its infancy in ancient Greece, Europeans had known and appreciated the fact that all human beings are not equally endowed intellectually. In their effort to refine the democratic process, early European thinkers made sure that intellectually-inferior citizens were kept out of the democratic processes. The voting right was one of the key democratic liberties which the intellectually-inferior citizens of Europe were barred from enjoying. To be specific, the class of Europeans who were barred from voting included "manual laborers, persons preoccupied with the soil, with crafts and small trade" (Habermas, p. 276). The policy which "prevented women from voting in the United States until the 1920s" (Horton \& Leslie, 1976, p. 224) had roots in the European policy which denied the voting right to subordinated persons.

Europe's medieval policy of denying the voting right to intellectually inferior citizens was not designed to be a permanent policy. The objective of the move was to use it as a process of purifying the electoral process. The idea of using the restriction of voting right as a purifying process was anchored on many beliefs. One of the beliefs was that "the men who possess a deeper insight into political life and its needs are never numerous in any age" (Habermas, 2001, p. 276). Another belief used to bolster the restriction of the voting right was that "a single remarkable individual may see things correctly while the entire world about him has wrong view" (Habermas, 2001, p. 276). The two Habermasian views cited above resonate with those of Alexis de Tocqueville and J. S. Mills. As cited in (Habermas, 2001, p. 136), Tocqueville had argued that "public opinion determined by the passions of the masses was in need of purification by means of the authoritative insights of materially independent citizens." J. S. Mills had also advocated that "political questions needed to be decided by a direct appeal to views formed after the consideration of a relatively small number of persons specifically educated for such task" (Habermas, 2001, p.136).

The founding fathers of modern European states did not doubt the verity of the cited views. For instance, J. S. Mill's suggestion that serious political question be reserved for only a small number of persons specifically educated for such task is vindicated by Horton \& Leslie's (1974, p.501f) claim that more than $75 \%$ of the population in every place and time is constituted by the hoi polloi. Also justifying Tocqueville's view regarding masses' public opinion is Wallas Graham's suggestion. Wallas suggests that “men are not entirely governed by reason but often by affection and instinct" (Jowett \& O'Donnell, 1999, pp. 104 \& 153).

Horton \& Leslie's, 1976, p. 224) view that majority of people in every space and time are made up of intellectually-inferior masses deserves to be properly understood. Proper understanding of the view requires highlightinghow indiscriminate extension of the voting right to every 18 yearold in a democratic process compares with allowing the public opinion of the masses to determine who rules. European founding fathers were aware that extending the voting right to every 18 year-old at a fledgling stage in a democratic experiment had the potential of contaminating the experiment. The awareness compelled them to restrict franchise to a small number considered 
competent enough to participate in a democratic process. Those who pioneered democratic rule in Europe did not relax the restriction on voting-right until they were satisfied that the pure insights of the mentally fit had purified the electoral process to a point where the uninformed passion of the masses would no longer corrupt the process. It was after the purification that the restrictions on voting right were removed.

While it lasted, the restrictions wielded positive influence on the electoral traditions of Europe and the United States. It, for instance, impressed upon the psyche of their contemporary politicians that the electorates are savvy, phlegmatic and cannot accept inanity in place of sound political communication. On the part of the media, the initial restriction of voting rights alerted the media to the fact that the electorates know their rights and would punish any media organization perceived as playing a "guard dog" instead of a "watch dog" role (Berger, 2000, p. $84)$.

\section{Flirting with Unpurified Electoral Process}

Because of its appeal and popularity, many countries have copied the idea of a democratic multiparty electoral system. Worse still, many of such copy-cat countries have heightened their copying mentality with the policy of granting the voting right to everybody above the age of 18 . Nigeria's copying of the policy of granting the voting right to every adult of 18 -years and above has spawned many unpalatable repercussions. The first is that such policy has resulted in a situation where majority of Nigerian electorates are the hoi polloi. Political philosophers, J. S. Mills and David Riesman as cited in (Habermas, 2001, pp. 249 \& 216) had stressed that a country would face intractable electoral challenges if it commences its electoral experiment with electorates with majority as common people. According to David Riesman as cited in (Habermas, 2001 , p. 216), the problem with an electoral process where a huge percentage of the electorates are commoners stems from the erratic political character of the masses. Riesman's description of the negative political traits of the masses, whom he derided as the "new indifferents," (Habermas, 2001, p. 216) is as follows:

They (the riffraff) are not necessarily equivalent to non-voters: these indifferents may perform quite a few political chores for a price under pressure. Nor are they devoid of political opinions.... But ... these political opinions are connected neither with direct political self-interest nor with clear emotional ties to politics. They resemble rather, the peer-group exchange of consumption preferences, though unlike the latter, the preferences are seldom taken into the political market and translated into purchases of political commodities. For the indifferent do not believe they can buy a political package that will substantially improve their lives. And so, subject to occasional manipulations, they tend to view politics in most of its large-scale forms as if they were spectators.

Where majority of the electorates are ill-informed, politicians take advantage of such anomaly. Nigeria politicians prefer unintelligent campaigns. They are drawn to it because they know that most of the electorates are ill-informed. Ill-informed electorates cannot distinguish polished communication campaign from a clumsy one. Even at that, polished communication campaign costs more. Nigerian politicians know this. As a result, they avoid costly campaigns. When they avoid costly campaigns, their confidence is shored up by what John Hahn identifies as the "art of saying nothing" (Hahn, 1998, pp. 102-107). Because majority of the electorates in Nigeria confuses "simplification for clarification," politicians exploit the confusion to bamboozle the hapless electorates into casting their votes on the basis of little or no understanding of the issues that matter (Hahn, 1998, p. 97).

Nigerian political campaign pundits decry the tradition of inane political campaigns. For instance, Oshunkeye(2011) had lamented the inanity of the 2011 election campaign in these words:

... As you leave the campaign venue, you ask yourself, what did he say? Journalists are asking the same question. Editors are scratching their heads on end; looking for quotable quotes... they hardly find any. The campaigns are dry and empty. They hardly address issues. What happens in most cases is a display of 
inanity... meaningless boastfulness about self as against service rendered...

Abati's (2003) lamentation before the 2003 elections in Nigeria demonstrates that inanity has been the defining feature of political campaigns in Nigeria. According to Abati:

... Meanwhile the political parties have been busy with campaign of personalities rather than issues; the parties are almost looking like clones of one another. One week to the elections, the public has no idea where the polling booths would be. There has been no systematic enlightenment of voters.

In a similar vein, Ejiogu (2003) had lamented: "so far, there has been some campaign. If only there were enough issues to differentiate the parties. As it is, all of them sound alike, feel alike, making an intelligent choice almost impossible." If inane campaigns were the only abnormality that rubbishes political communication in Nigeria, the worry might not be much. What heightens the absurdities of the Nigerian electoral process is the trivialization of traditions and standards. In advanced democracies for instance, opinion polls are considered sacred and respected during election seasons. But in the farce called electioneering campaigns in Nigeria, everything including opinion polls is desecrated. According to Odunaro, (2003), The Guardian and Tribune newspapers had conducted an opinion poll to determine electorates' preference between gubernatorial candidates of two major parties - Alliance for Democracy (AD) and Peoples Democratic Party (PDP) in Ogun State during the 2003 electioneering campaigns.

According to Odunaro, The Guardian newspaper, a paper widely known in Nigeria for conducting and publishing credible polls, had published a result of its poll to show that the electorates favored the Alliance for Democracy candidate at a ratio of $64 \%$. But within the same week, the Tribune, a newspaper not known for conducting opinion polls, cooked up its own poll result. The cooked-up result reversed the one of Guardian newspaper by the same margin in favor of Peoples Democratic Party's candidate. The major factor that robbed Tribune's report of any grain of credibility, according to Odunaro, was that the name of the agency that conducted the poll was not mentioned. Additionally, Odunaro informed that the methodology purported to have been used in the Tribune poll was at variance with any known method for conducting an opinion poll.

Up to this point, this paper has articulated the frustrating reality of empty political campaigns in Nigeria. Data are present in the following paragraphs to examine further, the pervasiveness of the culture of inane campaigns in Nigeria.

\section{Procedure}

The theoretical thrust of this paper is that politicians do not bother with issue-based political communication campaign in places like Nigeria where majority of the electorates are not intellectually complicated. In the light of this theoretical position, theoretical sampling was used to gather data. When used as a sampling method in qualitative research, theoretical sampling aims at "selecting groups or categories on the basis of their relevance to a paper's theoretical proposition and/or on the basis of the account or explanation the researcher seeks to develop" (Silverman \&Marvasti, 2008, p. 167).

To confer validity to their research, researchers who use theoretical sampling do so within the rubrics of "maximum variation" (Lindlof\& Taylor, 2002, p. 123). As a common strategy in qualitative research, maximum variation taps into a wide range of qualities, attributes, situations and exemplars that are germane to the phenomenon under investigation. Beyond the use of maximum variation to tap "typical and unique data," (Wodak \& Meyer, 2006, pp. 18 \& 99), I also used "context stripping method" (Maxwell, 1996, pp. 76 \& 78; Myer, 1997, p.10) to categorize the selected textual data for analysis. When textual data are context-stripped as I did in this paper, the texts are broken into their basic signifying components to facilitate comparison and interpretation.

\section{Method of Data Analysis}

When textual data are context-stripped, analysis of such data is usually done by means of "Hermeneutic circle" (Myers, 1997, p.10; Gripsrud, 2002, p. 133). When used as a tool for textual analysis, hermeneutic circle displays the dialectic between understanding of the text as a whole and the interpretation of its parts. According to Reinard, (1994, p. 134) "researchers use 
this approach when they want to focus on message qualities that are unique rather than generic." In the above light, the following textual exemplars are presented and interpreted as follows:

Table 1: Anatomy of Empty Campaign Messages

\begin{tabular}{|l|l|l|}
\hline S/No & Newspaper \& Dates & Textual Exemplars \\
\hline 1. & Hard Truth: March 3,2011, p. 12 & $\begin{array}{l}\text { To reduce ignorance and prepare } \\
\text { our people for the world of work. }\end{array}$ \\
\hline 2. & Daily Sun: March 21,2011 p.9 & $\begin{array}{l}\text { PDP and ACN in AkwaIbom State } \\
\text { have continued to trade words } \\
\text { over membership }\end{array}$ \\
\hline 3. & Daily Sun: March 21, 2011, p.9 & $\begin{array}{l}\text { TimiAlaibe campaign organization } \\
\text { decries verbal attacks on Alaibe }\end{array}$ \\
\hline 5. & Daily Sun: 21, 2011 p. 24 & $\begin{array}{l}\text { Fashola, an aberration in ACN } \\
\text { The Nation: March 20,2011, p.5 }\end{array}$ \\
\hline 6. & $\begin{array}{l}\text { The Northern Leaders told } \\
\text { Jonathan that after 2015, power } \\
\text { must return to the North }\end{array}$ \\
\hline & The Nation: March 20,2011, p.5 & $\begin{array}{l}\text { Four people suspected to be } \\
\text { working for the PDP in Oyo State } \\
\text { were yesterday arrested while } \\
\text { filling data into laptops belonging } \\
\text { to INEC }\end{array}$ \\
\hline
\end{tabular}

\section{Analytic Interpretation}

The attitude of politicians towards political communication draws the attention of political communication pundits. (Hahn, 1998, p. 102), for instance, believes that "the mistake many newcomers to politics make is to say something." Nigerian politicians are skilled at saying nothing during campaigns. Nigerian politicians get away with their art of saying nothing because of Nigeria mass media's ineptitude and/or connivance at the anomaly. Given the fact that the trick of not saying something has become a high art in politics, Nigerian journalists ought to draw on communication models with potentials to thwart politicians' disdain for intelligent political communication campaigns.

Apart from Mayhew's (1997, pp. 212-215) treatise on how to use "opinion polls to encourage issuebased political campaigns" much of the tenet of public journalism theory is instructive regarding how to compel politicians to say something. Encapsulated, public or civic journalism theory charges journalists to avoid seeing their role merely as that of "information disseminators" but more as "facilitators of public debate" and sometimes "active leaders in such debates" (Anderson \& Ross, 2002, p. 291f; Friend, Challenger \& McAdams, 2000, pp. 228 - 231; Rosen, 1999).

If Nigerian journalists had paid heed to the tenet of public journalism, the endemic orgy of inane political campaigns in Nigeria would not have firmed up to spawn some of the exemplars displayed in Table 1 above. The first exemplar in that table was sampled from the political campaign manifesto of one of the parties that contested the 2011 gubernatorial election in Rivers State. Exemplar 1 is a sentence that a political party used to articulate its education vision. Many critical scholars might read the style used for couching that vision is manipulative. Scholars who may read it as manipulative could ground the charge of manipulation on the premise that the sentence was not constructed as a declarative sentence. The failure to couch that sentence as a declarative sentence makes it to read like a mere "prediction" (Fairclough, 2001, p.213). That sentence ought to have been, for instance, constructed to read as follows: "my party shall guarantee every person the opportunity to access quality education from...' If the education-manifesto sentence had been constructed in the italicized style, such a style would have won the endorsement of critical scholars. Critical scholars would have grounded their endorsement of such style on the existence of an "identifiable agent" - 'my party' (Fairclough, 2001, p. 213). If the sentence had been constructed in the suggested style, it would also have eliminated the ideological baggage which 'our' - "an inclusive pronoun" (Fairclough, 2001, pp. 148-149 \& 160) brought in to further damage the sanctity of the sentence displayed as exemplar 1, Table 1. For avoidance of doubt, inclusive use of pronouns like: we, our and so on is often drawn on by the powerful to "pass off their preferences, desire, practices, perceptions as those of the people (Fairclough, 2001, p. 149).

In Table 1, exemplars 2 to 5 instantiate an enduring political communication flaw in Nigerian. In Nigeria, politicians construct their fellow Nigerian compatriots as a people whose "involvement in politics is less and less as citizens but more and more as political consumption communities" (Fairclough, 2001, p. 175). Constructing Nigerian electorates as a community of political consumers erroneously portrays Nigerian electorates as electorates who care more about where the president comes from than as electorates who yearn/deserve to be engaged with burning political issues like unemployment and lack of electricity.

"Structural amnesia" (Kunzik, 1995, p.161) is a concept used to describe "snippet journalism" (Kunczik, 1995, p. 149). While structural amnesia describes a flaw where journalists ignore and/or forget the need to report every angle of a story, snippet journalism is instantiated in a context where pursuit of topicality in news, wittingly/unwittingly, compels journalists into informing their audiences superficially about events and issues that deserve comprehensive coverage. For this paper, exemplar 6 of Table 1 represents a worrying incident of 
structural amnesia on the part of the Nigerian mass media. Given the fuss that preceded the 2011 general elections and given also the touted commitment of various stakeholders to give Nigerians a transparent election, the media were expected to follow to a logical juncture, the incident of the persons that were caught tampering with the gadgets that were designed to guarantee free and fair elections in 2011. But did the Nigerian media do that? In this instance, as in so many similar cases, the media muffed it. Rather than doing an investigative follow up, the bug of topicality (Kunczik, 1995, pp. 33, $49 \&$ 197) bit The Nation newspaper - the newspaper that broke the news of the gadget-tampering. The Nation newspaper's atomized treatment of that news is cited as exemplar 6 of Table 1. When another newspaper, Daily Sun dabbled into the same story the following day, the same bug of topicality also impelled it to give just a mere snippet treatment of the story.

\section{Conclusion}

The view pursued in this paper is that Nigerian politicians usually feel happy because the electoral process guarantees them victory even when docile media fail to compel them to get involved in intelligent communication campaigns. This paper also believes that the adoption in Nigeria of the public journalism model of communication by the mass media will compel Nigerian politicians to start articulating logical political communication campaigns during elections. Additionally, this paper canvasses the view that politicians' predilection to avoid issue-based campaign is higher where the voting right is indiscriminately given to every person of 18 years of age. A synthesis of these theoretical positions provided the premise to hypothesize that where the voting majority is not cerebral as a result of indiscriminate extension of voting right to every 18 year old, politicians will continue to see no reason to run intelligent, issue-based campaign.

\section{References}

[1]. Hahn, D. (1998). Political communication. Pennsylvania: Strata Publishing INC.

[2]. Mayhew, L. (1997). The new publics. London: Cambridge University Press.

[3]. Keane, J. (1995). Democracy and media: without foundations. In O. Boyd-Barrett \& C. Newbold (Eds.),Approaches to media. London: Arnold.

[4]. Melody, W. ( 1990). Communication policy in the global information economy: wither the public interest? In M. Ferguson ( Ed.).Public communication. London: Sage Publications.

[5]. Webster, F. (2011). Information and democracy: the weakening of social democracy. In S. Papathanassopoulos (ed.), Media perspectives for the $21^{\text {st }}$ century. New York: Routledge

[6]. Chandler, D. (2010). The transmission model of communication.Accessed 27 $7^{\text {th }}$ December, 2010.www.aber.ac.uk/media/document/short/trans.html

[7]. Anderson, R. \& Ross, V. (2002). Questions of communication. Boston \& New York: Bedford/St. Martins.

[8]. Reddy, M. (1979). The conduit metaphor.In A. Ortony (Ed.), Metaphor and thought.Cambridge: Cambridge University Press.

[9]. Hardt, H. (2004). British cultural studies and the return of the critical in American mass communication research: accommodation or radical change? In: D .Morley, \& K. Chen, (Eds.). Critical dialogue in cultural studies. London: Rutledge. Pp. $102-111$.

[10]. Kunczik, M. (1995). Concepts of journalism north and south. Bonn: Friedrich Ebert Foundation.

[11]. Habermas, J. (2001). The structural transformation of the public sphere. Massachusetts: the MIT Press.

[12]. Gripsrud, J. (2002). Understanding media culture. London: Arnold.

[13]. Gouldner, A. (1976).The dialectics of ideology and technology. London: Macmillan Press Ltd.

[14]. Littlejohn, S. (1996). Theories of human communication.Toronto: Wadsworth Publishing Company.

[15]. Friend, C., Challenger, D. \& McAdams, K. (2000). Contemporary editing. Chicago: NTC/Contemporary Publishing.

[16]. Rosen, J. (1999). What are journalists for? London: Yale University Press.

[17]. Horton, P. \& Leslie, G. ( 1974). The sociology of social problems. New Jersey: Prentice-Hall, Inc.

[18]. Jowett, G. \& O’Donnell, V. (1999). Propaganda and persuasion. London: Sage Publications, Inc.

[19]. Berger, G. (2000). Grave new world? Democratic journalism enters the global twenty-first century. Journalism studies 1(1). Journalism studies, pp.81-99.

[20]. Oshunkeye, S. (2011, March 27). “ Those bland, hollow campaigns...” Sunday Sun, p. 71.

[21]. Abati, R. (2003, April 6). "A week to the elections." The Guardian, p.22.

[22]. Ejiogu, B. ( 2003, April, 6). " Suffering and voting." Guardian, p.21.

[23]. Odunaro, K. (2003, March 29). “The Ogun State race.”ThisDay, p.8.

[24]. Silverman, D. \&Marvasti, A. (2008). Doing qualitative research: a comprehensive guide. London: Sage Publications.

[25]. Lindlof, T. \& Taylor, B. (2002).Qualitative communication research methods. London: Sage Publications.

[26]. Wodak, R. \& Meyer, M. (2006).Methods of critical discourse analysis. London: Sage Publications.

[27]. Maxwell, J. (1996). Qualitative research design: an interactive approach. London: Sage Publications.

[28]. Myers, M. (1997). "Qualitative research in information systems. Retrieved June 16, 2007 from http://www.qual.auland.ac.nz/

[29]. Reinard, J. (1994).Communication research. Wisconsin: WCB Brown \&Benchmark Publishers.

[30]. Fairclough, N. (2001). Language and power. London: Longman. 